\title{
Exercise May Affect Metabolism in Cancer-Related Cognitive Impairment
}

\author{
Muhammad Shahid ${ }^{1}$ and Jayoung $\operatorname{Kim}^{1,2,3,4, *}$ \\ 1 Departments of Surgery and Biomedical Sciences, Cedars-Sinai Medical Center, Davis 5071, 8700 Beverly \\ Blvd., Los Angeles, CA 90048, USA; muhammad.shahid@cshs.org \\ 2 Samuel Oschin Comprehensive Cancer Institute, Cedars-Sinai Medical Center, Los Angeles, CA 90048, USA \\ 3 Department of Medicine, University of California Los Angeles, Los Angeles, CA 90024, USA \\ 4 Department of Urology, Ga Cheon University College of Medicine, Incheon 461-701, Korea \\ * Correspondence: Jayoung.Kim@cshs.org; Tel.: +1-310-423-7168; Fax: +1-310-967-3809
}

Received: 7 August 2020; Accepted: 18 September 2020; Published: 20 September 2020

check for updates

\begin{abstract}
Cancer-related cognitive impairment (CRCI) is a significant comorbidity for cancer patients and survivors. Physical activity (PA) has been found to be a strong gene modulator that can induce structural and functional changes in the brain. PA and exercise reduce the risk of cancer development and progression and has been shown to help in overcoming post-treatment syndromes. Exercise plays a role in controlling cancer progression through direct effects on cancer metabolism. In this review, we highlight several priorities for improving studies on CRCI in patients and its underlying potential metabolic mechanisms.
\end{abstract}

Keywords: cancer-related cognitive impairment; therapeutic exercise intervention; metabolism; metabolomics profiling

\section{Introduction}

From the total global population, $13 \%$ are adults 60 years or older, which accounts for approximately 962 million people. This group is predicted to steadily increase in population to 1.4 billion, 2.1 billion, and 3.1 billion by 2030, 2050, and 2100, respectively [1]. Patients with cognitive impairment (CI) make up a large number of adults in the 60 years or older population. These patients may experience difficulties in daily functioning, decision-making, and treatment adherence; thereby, leading to reduced quality of life (QoL) and decreased survival [2,3]. In an effort to maintain independence in older adults, focusing on cognitive function is a novel target of concern, since the origins of cognitive decline may be reversible or even treatable. As a result, understanding cognitive decline in older adults is a growing field of interest. CI can also lead to increases in caregiver burdens. Prevention of CI in cancer patients is especially important for older patients, since there have been notable increases in long-term survival due to new treatments and a resulting growing number of people living with cancer as a chronic condition. The spectrum of cognitive decline between normal cognitive and mild cognitive impairment $(\mathrm{MCI})$ to dementia in older adults can range from natural cognitive decline due to age to atypical cognitive impairment [1]. The prevalence rate in the group of adults older than $60 \mathrm{MCI}$ showed increasing with age and lower levels of education which is approximately $6.7 \%$ to $25.2 \%$, and is more prevalent in men [4,5].

\section{CI in Cancer Patients}

Cancer and treatments for it, including chemotherapy, hormone therapy, and radiation therapy, can have harmful effects on mental processes [6,7]. Previous studies reported a higher incidence of cognitive dysfunction among cancer patients compared to healthy matched controls. Up to $85 \%$ of 
cancer patients receiving treatment have been found to report mild to severe cognitive complaints, which can last months to even years after finishing treatment [8]. Cancer-related CI (CRCI) can be classified as subtle, moderate, or severe based on neuropsychological testing. CRCI is the most frequent complication reported by breast cancer patients [9]. Cognitive complaints have been reported by more than $50 \%$ of breast cancer patients following chemotherapy; however, only $15 \%-25 \%$ of these patients have shown objective cognitive decline [10]. Demographic and other health factors, such as age, race, socioeconomic status, education, menopausal status, and body mass index, are also known to affect cognition in adults [11,12]. Since difficulties in cognitive function have a negative impact on QoL (autonomy, work balance, relationships, and self-image), there is an urgent need for more pronounced CRCI management in patients. This has fueled studies on potentially implementing cognitive rehabilitation for cancer patients [13]. In light of the prevalence and associated individual burden of CRCI, there is a clear need for strategies to manage CRCI. Currently, there are no established treatment options to reduce CRCI risk or diminish its severity [14,15]. Furthermore, advancements in hormone therapy, targeted therapy, and immunotherapy have resulted in greater survival rates for cancer patients, but at the cost of increased potential cognitive impacts [16].

The precise mechanisms underlying the pathophysiology of CRCI are unclear. Demographic factors, including age, race, socioeconomic status, and education, as well as menopausal status, health status, and body mass index, are also known to affect cognition in adults. In light of the prevalence and associated individual burden of CRCI, there is a clear need for strategies to manage CRCI. Currently, no established treatment options exist to reduce the risk of CRCI or diminish its severity. Campbell et al., performed a systematic analysis of 29 randomized controlled trials (RCTs) to better understand the relationship of exercise with CRCI. In 12 of these trials (41\%) (Cohen d range: 0.24-1.14), they found that exercise had a significant effect on self-reported cognitive function during and after chemotherapy. These 12 trials used the EORTC QLQ-C30 exam for cognitive functioning. In 10 other trials (34\%), neuropsychological testing was used to evaluate cognitive functioning; however, only 3 of these trials in breast cancer reported significant benefits from exercise (Cohen $\mathrm{d}$ range: 0.41-1.47) [17].

Another study by Witlox et al. found that physical exercise had positive effects in healthy older adults and those with mild cognitive impairment. They recruited 180 breast cancer patients with cognitive issues 2-4 years after their diagnosis with cancer and randomized them (1:1) into two groups; exercise intervention and control. The exercise intervention group underwent a 6-month course of twice weekly $1 \mathrm{~h}$ supervised aerobic and strength-training exercises with twice weekly $1 \mathrm{~h}$ power walking. They concluded that physical exercise improves cognitive functioning for breast cancer survivors [18].

To better understand CRCI's pathophysiology and the direct impact of different cancer treatments, animal models have been developed [19].

\section{Biological Drivers of CRCI}

Evidence from clinical and pre-clinical research suggests that many mechanisms play a role in the development of CRCI, including inflammation [20,21]. Inflammation is an important mechanism underlying cognitive impairment, especially in the elderly. Accumulating evidence has linked inflammation to cognitive decline and the risk of dementia [22]. Chemotherapy-induced pro-inflammatory cytokines levels of interleukin (IL)-1 $\beta$, IL-6, tumor necrosis factor- $\alpha$ (TNF- $\alpha$ ), and IL-10 in cancer patients have been related to possible CI [23,24]. A large multicentered cohort study conducted in Singapore found that among proinflammatory plasma cytokines-including IL-1 $\beta$, IL-2, IL-4, IL-6, IL-8, IL-10, granulocyte-macrophage colony-stimulating factor, interferon- $\gamma$, and TNF- $\alpha$-elevated IL- $1 \beta$ and IL- 6 were associated with greater self-reported cognitive impairments ( $p=0.018$ and 0.001 , respectively) [25]. However, the effects of cytokines in post-chemotherapy cognitive impairment remains in controversy; other studies have published conflicting results about the relationship between cytokine concentration and cognition $[26,27]$. Nonsteroidal anti-inflammatory 
drugs (NSAIDs) have often been administered as a preventative measure against Alzheimer's disease (AD). The mechanism of action is believed to be through blockage of cyclo-oxygenase isoforms (e.g., COX-1 and COX-2). NSAIDs have neurotoxic and neuroprotective effects with diverse impacts on mechanisms that may influence cognitive impairment, including inflammation, release of neurotransmitters, synaptic plasticity, cerebral ischemia, and functioning of cerebral endothelial and smooth muscle [28].

Oxidative stress and its associated damage in the age-dependent cognitive loss has been previously highlighted [29]. Chemotherapy-induced oxidative stress-mediated TNF- $\alpha$ triggers inducible nitric oxide synthase (iNOS) production [30]. Apolipoprotein A-I (ApoA1) is possibly one of the key factors in oxidative stress and pro-inflammatory cytokine mediated CRCI. Oxidation and down-regulated expression of ApoA1 were found in a number of neurodegenerative diseases with cognitive deficits, such as Alzheimer's and Parkinson's Diseases [31]. Administration of vitamin E ameliorated memory deficit. Vitamin E-deficient rats showed decreased learning as well as memory retention ability, whereas younger rats supplemented with vitamin E displayed accelerated learning and capabilities. This could be that learning ability declined gradually with age due to chronic exposure to oxidative stress [32]. The association of DNA damage with aging is well-studied [33]. DNA lesions are accumulated in the brain during AD. Elevations in $\gamma \mathrm{H} 2 \mathrm{AX}$, a well-established marker of double-strand breaks (DSB) [34], were detected in 11 of $13 \mathrm{AD}$ brains in the astrocytes of the hippocampus and cerebral cortex [35]. Studies on two independent cohorts $(n=13$ and $n=23)$ found significant increases of $\gamma \mathrm{H} 2 \mathrm{AX}$ in the astrocytes and neurons of the hippocampus and frontal cortex of AD brains; this increase was found in brains with MCI as well [36]. Other factors include reduced synaptic plasticity, altered growth factor levels, and impaired hippocampal neurogenesis [37-39].

\section{The Interrelationship between CRCI and Alterations in Metabolism}

In addition to powering live systems, metabolism is a complex phenomenon that is tightly linked to signaling pathways, post-translational modifications, and gene expression. In general, metabolism acts as a cellular rheostat [40]. Metabolism supports a variety of normal cell functions, including breakdown of carbohydrates, fats, and amino acids to generate energy and biosynthetic precursors needed for growth [41]. The fundamental features of metabolism are reprogrammed in cancer cells to support their aberrant growth and proliferation. This change in functioning is likely the result of genomic alterations (i.e., mutations in oncogenes and tumor suppressor genes), tumor microenvironment (compromised nutrients and oxygen availability), and other factors [42]. Metabolic alterations are a hallmark of cancer [43]. These changes favor rapidly dividing cells, inhibit the prevention of tumor initiation, and attenuates proliferation and metastasis [44]. In order to better understand cancer-specific metabolism, a systemic application of analytical techniques that can assess metabolic levels is needed.

Metabolomics combines high-throughput analysis with bioinformatics and aims to comprehensively analyze all metabolites in a given biological sample. Over the past 20 years, incredible advancements have been made in metabolomics. This has propelled its evolution into becoming a powerful tool in medicine and science, especially in the study of disease-related biomarkers, toxicology, and molecular mechanisms. Metabolomics can also provide greater detailed information regarding human biochemistry [45,46]. Metabolomics is commonly applied to discover diagnostic, prognostic, or therapeutic biomarkers [47]. For instance, early metabolomic experiments in breast cancer patients lead to the identification of positive associations between choline, glycine, and lactate with tumor grade and size [48]. Similar work has now been done in ovarian [49], prostate [50], and various other cancers. Since the efforts of metabolomics-based biomarker discovery have been well summarized in previously published review papers as described above, we will not further discuss the topic in this article.

Since its first observation 90 years ago by Dr. Otto Warburg, one of the hallmarks in cancer biology is the metabolic reprogramming such as high rates of aerobic glycolysis [51-54]. Cancer-associated metabolic alteration has been reported in many types of cancers. Amino acids, such as arginine, proline, 
glutamine, and creatine, play important roles as substrates and protein synthesis in cancer cells and they have been widely studied in cancer metabolism. Specific metabolic pathways altered by cancer have also been reported, which provide therapeutical strategies. Metabolic reprogramming is considered for regimens an exploited for cancer therapy. Amino acid depletion therapies are being tested against several cancer types $[55,56]$. For example, metformin, an inhibitory drug of mitochondrial metabolism, has been suggested to have a synergistic effect when used with chemotherapies by inhibiting proliferation of cancer cells [57,58].

Doxorubicin (DOX) is a widely used antitumor agent for the treatment of a series of cancer types. However, DOX shows cytotoxicity to noncancer cells such as heart, skeletal muscle, liver, and kidney cells, leading to adverse effect. Recently, exercise is reported to show a beneficial adaptation to reduce the DOX-induced cellular toxicity [59]. However, the mechanisms underlying the exercise-induced protection against DOX cytotoxicity are not clear. Exercise has another benefit, reducing cognitive impairment. Brain-derived neurotrophic factor (BDNF), a key mediator of cognitive impairment in Alzheimer's dementia. A recent finding suggested that exercise-induced expression of BDNF, suggesting the potential mechanism of exercise benefit to increase cognitive function [60].

Prior studies have also provided essential information on the occurrence and association of metabolic alterations and cognitive impairment in humans. However, they have not established the molecular mechanisms behind these relationships, nor the therapeutic window that would allow for treatment before irreversible damage occurs in both systemic functionality and cognitive skills.

Different lifestyle factors are involved in the arise of diseases which may also lead increasing the risk of developing AD. Lifestyle factors are increasingly being recognized for their role in figuring out cognitive impairment, or the lack thereof, with age. Participation in recreational physical activity (PA) has been shown to be inversely related to the prevalence of age-related cognitive decline and dementia [61]. Independent studies have repeatedly shown that PA reduces cognitive decline in older age groups [62]. Similarly, several studies have also shown that due to the limited use of diet or diet restraint is resulted with the maintenance of cognitive function later in life [63].

Omega-3 fatty acids and antioxidants are specific dietary components which preserves cognitive function. Daily intake of these components works well for the eighth decade of life [64]. Glucose and insulin metabolism are key metabolic pathways and represents a metabolic spectrum with clinical thresholds for prediabetes and diabetes mellitus. Further increases in fasting glucose, with concomitant impairment of both glucose and insulin metabolism, are hallmarks of type 2 diabetes. Obesity is a known significant risk factor of AD progression for both prediabetes and diabetes [63]. Possible mechanisms underlying metabolic reserves in $\mathrm{MCI}$ and $\mathrm{AD}$ involve direct roles for insulin [65], insulin-like growth factors [66], and neurotrophic factors [67], as well as pathological changes in glucose metabolism and protein glycosylation [68]. Other components of the hormonal milieu include adipocyte cytokine leptin [69].

\section{Role of Exercise in CRCI}

According to the World Health Organization's definition, any bodily movement that involved skeletal muscles by utilizing energy is called PA; whereas, well planned, structured, repetitive, and intentional movement known as exercise, which is a subcategory of PA. Most observational studies assess PA rather than exercise. Based on multiple meta-analyses, physical exercise is known to be crucial for maintaining general health [70,71]. Exercise helps maintain body weight and reduces stress. People who regularly exercise are less likely to smoke tobacco or overeat. Moreover, exercise directly targets the primary aspects of health, including heart function, cholesterol, triglycerides, blood pressure, and brain function. It has been shown that regular exercise leads to enhanced maximal oxygen uptake and increases the mean lifespan of laboratory animals and humans [72]. Exercise is known to impact almost every system in the body. Benefits include improved cardiovascular health, greater bone mineral density (BMD), and decreased risk of cancer, stroke, diabetes, and cognitive impairment. 
Exercise is an established safe and effective therapy for managing numerous adverse effects of cancer treatment, including fatigue, psychological distress, functional decline, and detrimental body composition changes [73]. Accumulating evidence on the positive role of exercise on improving cognitive function in healthy older adults and those with mild cognitive impairment or more severe neurocognitive impairment (i.e., $\mathrm{AD}$, stroke) has sparked significant interest in the potential use of exercise as an effective management strategy for CRCI [74-76]. A variety of evidence supports the conclusion that exercise link to cancer which could lower the risk of different cancers including colon, breast, kidney, endometrial, bladder, esophageal, and stomach cancers, with moderate evidence for lung cancer. The Physical Activity Guidelines Advisory Committee determined and vigorously appreciated the conclusion [77].

Unfortunately, due to limited preclinical studies and testing of the antitumor activity of exercise is restricted. So far, only 53 studies were reported in vivo preclinical testing to assess the activity of various exercise paradigms on tumor incidence, growth, or metastasis; 35 of these studies positively reported that exercise inhibited cancer growth or progression [78]. More recently, higher-quality studies have demonstrated that paradigms of PA showed a link between exercise and epinephrine, and IL- 6 to NK cell mobilization and redistribution; both of which ultimately control tumor growth [79].

Benefits of exercise were particularly noted on self-reported cognitive function in women with breast cancer [80]. RCTs have suggested that people should adopt PA and exercise to alleviate the negative impacts of aging on cognitive function. Through a meta-analysis, Heyn P. et al. found that PA and exercise had positive effects on cognition among those with cognitive decline [80].

\section{The Effects of Exercise on Cancer Metabolism and Its Associated Signaling Pathways}

The role of PA and exercise in the whole process of cancer from prevention to post-treatment has been extensively studied [70,81]. There is ample evidence suggesting regular PA to be related to a reduced risk for various forms of cancer [82]. Exercising at varying intensities has been found to have remarkable effects on physiologic and gene expression adaptations in mammals [83]. The role of exercise has surprisingly received little to no attention in high-risk individuals. However, recently, a larger number of groups are investigating the effects of PA and exercise on cancer; a field now called "exercise-oncology" [84]. In cancer patients, exercise is now well-documented to be a tolerable adjunct therapy associated with significant benefits across a wide range of symptoms [85].

Intratumoral signaling networks are highly modifiable and modulated by numerous extrinsic factors [86]. Vulczak et al. demonstrated that the mitochondrial activity of tumor cells in animals that exercised was lower in comparison to the tumor cells of sedentary animals, with a significant decrease in the electron transport chain capacity (E). This demonstrates lower respiratory capacity independent of mitochondrial content, measured by citrate synthase (CS) activity [87]. Kynurenine (KYN), a catabolite of the amino acid tryptophan (TRP), was found to be associated with progression and poor clinical outcome in numerous cancer types [88]. Zimmer et al. and his team investigated the influence of resistance exercise on the KYN pathway in breast cancer patients. They showed the potential exercise-induced modulation of KYN pathway metabolites in the serum and urine of healthy women and breast cancer patients undergoing radiotherapy [89]. The Akt/mTOR pathway is central for controlling growth and protein synthesis and plays a pivotal role in the muscular response to resistance training [90]. Thompson et al. reviewed several preclinical studies highlighting how the $\mathrm{Akt} / \mathrm{mTOR}$ pathway is differentially regulated with exercise in many tumor types [91].

\section{Conclusions}

In conclusion, current evidence suggests that physical exercise shows much promise in improving cognitive impairment among cancer patients and survivors. Exercise also shows much influence on cancer incidence, lowers the risk of recurrence, and secures longer higher quality life for patients. Most of cancer patients expressed their preferences in the therapeutic potential of exercise over chemotherapeutics; this strategy may potentially alter disease pathogenesis and symptoms without the 
adverse effects of conventional pharmacological agents. The positive effects of exercise are evident in large epidemiological studies, as well as controlled laboratory studies. Moreover, exercise inhibits tumor growth across cancers and at all stages of tumor development. Given these findings, future research needs to consider the type of measurements used to measure CRCI, which will further improve patient care and lead to the development of targeted therapies, preventative strategies, and cognitive rehabilitation treatment.

Author Contributions: Research conception and design: J.K. Drafting of the manuscript: M.S. Critical revision of the manuscript: J.K. Supervision: J.K. Approval of the final manuscript: All authors. All authors have read and agreed to the published version of the manuscript.

Funding: The authors acknowledge support from National Institutes of Health grants (grant nos. 1U01DK103260, 1R01DK100974, U24 DK097154 and NIH NCATS UCLA CTSI UL1TR000124), Department of Defense grants (grant nos. W81XWH-15-1-0415 and W81XWH-19-1-0109), Centers for Disease Controls and Prevention (grant no. 1U01DP006079), IMAGINE NO IC Research Grant, the Steven Spielberg Discovery Fund in Prostate Cancer Research Career Development Award, and the U.S.-Egypt Science and Technology Joint Fund. This research was partly supported by the Samuel Oschin Comprehensive Cancer Institute at Cedars-Sinai Medical Center through 2019 Lucy S. Gonda Award (to J.K.). In addition, this article is derived from the Subject Data funded in whole or part by National Academies of Sciences, Engineering, and Medicine (NAS) and The United States Agency for International Development (USAID). Any opinions, findings, conclusions, or recommendations expressed in this article are those of the authors alone, and do not necessarily reflect the views of USAID or NAS.

Acknowledgments: The authors acknowledge support from National Institutes of Health grants (1U01DK103260, 1R01DK100974, U24 DK097154, NIH NCATS UCLA CTSI UL1TR000124), Department of Defense grants (W81XWH-15-1-0415 and W81XWH-19-1-0109), Centers for Disease Controls and Prevention (1U01DP006079), IMAGINE NO IC Research Grant, the Steven Spielberg Discovery Fund in Prostate Cancer Research Career Development Award, and the U.S.-Egypt Science and Technology Joint Fund. This research was partly supported by the Samuel Oschin Comprehensive Cancer Institute at Cedars-Sinai Medical Center through 2019 Lucy S. Gonda Award (to J.K.). In addition, this article is derived from the Subject Data funded in whole or part by National Academies of Sciences, Engineering, and Medicine (NAS) and The United States Agency for International Development (USAID). Any opinions, findings, conclusions, or recommendations expressed in this article are those of the authors alone, and do not necessarily reflect the views of USAID or NAS.

Conflicts of Interest: The authors declare no conflict of interest.

\section{References}

1. Jongsiriyanyong, S.; Limpawattana, P. Mild Cognitive Impairment in Clinical Practice: A Review Article. Am. J. Alzheimers Dis. Other Demen 2018, 33, 500-507. [CrossRef] [PubMed]

2. Robb, C.; Boulware, D.; Overcash, J.; Extermann, M. Patterns of care and survival in cancer patients with cognitive impairment. Crit Rev. Oncol. Hematol. 2010, 74, 218-224. [CrossRef] [PubMed]

3. Barrios, H.; Narciso, S.; Guerreiro, M.; Maroco, J.; Logsdon, R.; de Mendonca, A. Quality of life in patients with mild cognitive impairment. Aging Ment. Health 2013, 17, 287-292. [CrossRef] [PubMed]

4. Cheng, Y.W.; Chen, T.F.; Chiu, M.J. From mild cognitive impairment to subjective cognitive decline: Conceptual and methodological evolution. Neuropsychiatr. Dis. Treat. 2017, 13, 491-498. [CrossRef] [PubMed]

5. Valenzuela, M.; Sachdev, P.; Brodaty, H. Reader response: Practice guideline update summary: Mild cognitive impairment: Report of the Guideline Development, Dissemination, and Implementation Subcommittee of the American Academy of Neurology. Neurology 2018, 91, 372. [CrossRef]

6. Tannock, I.F.; Ahles, T.A.; Ganz, P.A.; Van Dam, F.S. Cognitive impairment associated with chemotherapy for cancer: Report of a workshop. J. Clin. Oncol. 2004, 22, 2233-2239. [CrossRef]

7. Brezden, C.B.; Phillips, K.A.; Abdolell, M.; Bunston, T.; Tannock, I.F. Cognitive function in breast cancer patients receiving adjuvant chemotherapy. J. Clin. Oncol. 2000, 18, 2695-2701. [CrossRef]

8. Falleti, M.G.; Sanfilippo, A.; Maruff, P.; Weih, L.; Phillips, K.A. The nature and severity of cognitive impairment associated with adjuvant chemotherapy in women with breast cancer: A meta-analysis of the current literature. Brain Cogn. 2005, 59, 60-70. [CrossRef]

9. Schmidt, J.E.; Beckjord, E.; Bovbjerg, D.H.; Low, C.A.; Posluszny, D.M.; Lowery, A.E.; Dew, M.A.; Nutt, S.; Arvey, S.R.; Rechis, R. Prevalence of perceived cognitive dysfunction in survivors of a wide range of cancers: Results from the 2010 LIVESTRONG survey. J. Cancer Surviv. 2016, 10, 302-311. [CrossRef] 
10. Lange, M.; Licaj, I.; Clarisse, B.; Humbert, X.; Grellard, J.M.; Tron, L.; Joly, F. Cognitive complaints in cancer survivors and expectations for support: Results from a web-based survey. Cancer Med. 2019, 8, 2654-2663. [CrossRef]

11. Janelsins, M.C.; Kesler, S.R.; Ahles, T.A.; Morrow, G.R. Prevalence, mechanisms, and management of cancer-related cognitive impairment. Int Rev. Psychiatr. 2014, 26, 102-113. [CrossRef] [PubMed]

12. Agrigoroaei, S.; Lachman, M.E. Cognitive functioning in midlife and old age: Combined effects of psychosocial and behavioral factors. J. Gerontol. B Psychol. Sci Soc. Sci. 2011, 66 Suppl 1, i130-i140. [CrossRef]

13. Lange, M.; Joly, F.; Vardy, J.; Ahles, T.; Dubois, M.; Tron, L.; Winocur, G.; De Ruiter, M.B.; Castel, H. Cancer-related cognitive impairment: An update on state of the art, detection, and management strategies in cancer survivors. Ann. Oncol. 2019, 30, 1925-1940. [CrossRef] [PubMed]

14. Ahles, T.A.; Root, J.C.; Ryan, E.L. Cancer- and cancer treatment-associated cognitive change: An update on the state of the science. J. Clin. Oncol. 2012, 30, 3675-3686. [CrossRef] [PubMed]

15. Gehring, K.; Roukema, J.A.; Sitskoorn, M.M. Review of recent studies on interventions for cognitive deficits in patients with cancer. Expert Rev. Anticancer Ther. 2012, 12, 255-269. [CrossRef] [PubMed]

16. Joly, F.; Heutte, N.; Duclos, B.; Noal, S.; Leger-Hardy, I.; Dauchy, S.; Longato, N.; Desrues, L.; Houede, N.; Lange, M.; et al. Prospective Evaluation of the Impact of Antiangiogenic Treatment on Cognitive Functions in Metastatic Renal Cancer. Eur. Urol. Focus 2016, 2, 642-649. [CrossRef]

17. Campbell, K.L.; Zadravec, K.; Bland, K.A.; Chesley, E.; Wolf, F.; Janelsins, M.C. The Effect of Exercise on Cancer-Related Cognitive Impairment and Applications for Physical Therapy: Systematic Review of Randomized Controlled Trials. Phys. Ther. 2020, 100, 523-542. [CrossRef]

18. Witlox, L.; Schagen, S.B.; de Ruiter, M.B.; Geerlings, M.I.; Peeters, P.H.M.; Koevoets, E.W.; van der Wall, E.; Stuiver, M.; Sonke, G.; Velthuis, M.J.; et al. Effect of physical exercise on cognitive function and brain measures after chemotherapy in patients with breast cancer (PAM study): Protocol of a randomised controlled trial. BMJ Open 2019, 9, e028117. [CrossRef]

19. Winocur, G.; Johnston, I.; Castel, H. Chemotherapy and cognition: International cognition and cancer task force recommendations for harmonising preclinical research. Cancer Treat. Rev. 2018, 69, 72-83. [CrossRef]

20. Rego, S.L.; Helms, R.S.; Dreau, D. Tumor necrosis factor-alpha-converting enzyme activities and tumor-associated macrophages in breast cancer. Immunol. Res. 2014, 58, 87-100. [CrossRef]

21. Korkaya, H.; Liu, S.; Wicha, M.S. Breast cancer stem cells, cytokine networks, and the tumor microenvironment. J. Clin. Invest. 2011, 121, 3804-3809. [CrossRef] [PubMed]

22. Sartori, A.C.; Vance, D.E.; Slater, L.Z.; Crowe, M. The impact of inflammation on cognitive function in older adults: Implications for healthcare practice and research. J. Neurosci. Nurs. 2012, 44, 206-217. [CrossRef] [PubMed]

23. Pomykala, K.L.; Ganz, P.A.; Bower, J.E.; Kwan, L.; Castellon, S.A.; Mallam, S.; Cheng, I.; Ahn, R.; Breen, E.C.; Irwin, M.R.; et al. The association between pro-inflammatory cytokines, regional cerebral metabolism, and cognitive complaints following adjuvant chemotherapy for breast cancer. Brain Imaging Behav. 2013, 7, 511-523. [CrossRef] [PubMed]

24. Lyon, D.E.; Cohen, R.; Chen, H.; Kelly, D.L.; McCain, N.L.; Starkweather, A.; Ahn, H.; Sturgill, J.; Jackson-Cook, C.K. Relationship of systemic cytokine concentrations to cognitive function over two years in women with early stage breast cancer. J. Neuroimmunol. 2016, 301, 74-82. [CrossRef] [PubMed]

25. Cheung, Y.T.; Ng, T.; Shwe, M.; Ho, H.K.; Foo, K.M.; Cham, M.T.; Lee, J.A.; Fan, G.; Tan, Y.P.; Yong, W.S.; et al. Association of proinflammatory cytokines and chemotherapy-associated cognitive impairment in breast cancer patients: A multi-centered, prospective, cohort study. Ann. Oncol. 2015, 26, 1446-1451. [CrossRef] [PubMed]

26. Ganz, P.A.; Bower, J.E.; Kwan, L.; Castellon, S.A.; Silverman, D.H.; Geist, C.; Breen, E.C.; Irwin, M.R.; Cole, S.W. Does tumor necrosis factor-alpha (TNF-alpha) play a role in post-chemotherapy cerebral dysfunction? Brain Behav. Immun. 2013, 30, S99-S108. [CrossRef] [PubMed]

27. Janelsins, M.C.; Mustian, K.M.; Palesh, O.G.; Mohile, S.G.; Peppone, L.J.; Sprod, L.K.; Heckler, C.E.; Roscoe, J.A.; Katz, A.W.; Williams, J.P.; et al. Differential expression of cytokines in breast cancer patients receiving different chemotherapies: Implications for cognitive impairment research. Support. Care Cancer 2012, 20, 831-839. [CrossRef]

28. Launer, L.J. Nonsteroidal anti-inflammatory drugs and Alzheimer disease: What's next? JAMA 2003, 289, 2865-2867. [CrossRef] 
29. Aluise, C.D.; St Clair, D.; Vore, M.; Butterfield, D.A. In vivo amelioration of adriamycin induced oxidative stress in plasma by gamma-glutamylcysteine ethyl ester (GCEE). Cancer Lett. 2009, 282, 25-29. [CrossRef]

30. Tangpong, J.; Cole, M.P.; Sultana, R.; Estus, S.; Vore, M.; St Clair, W.; Ratanachaiyavong, S.; St Clair, D.K.; Butterfield, D.A. Adriamycin-mediated nitration of manganese superoxide dismutase in the central nervous system: Insight into the mechanism of chemobrain. J. Neurochem. 2007, 100, 191-201. [CrossRef]

31. Keeney, J.T.; Swomley, A.M.; Forster, S.; Harris, J.L.; Sultana, R.; Butterfield, D.A. Apolipoprotein A-I: Insights from redox proteomics for its role in neurodegeneration. Proteomics Clin. Appl. 2013, 7, 109-122. [CrossRef] [PubMed]

32. Fukui, K.; Onodera, K.; Shinkai, T.; Suzuki, S.; Urano, S. Impairment of learning and memory in rats caused by oxidative stress and aging, and changes in antioxidative defense systems. Ann. N Y Acad. Sci. 2001, 928, 168-175. [CrossRef] [PubMed]

33. Lin, X.; Kapoor, A.; Gu, Y.; Chow, M.J.; Peng, J.; Zhao, K.; Tang, D. Contributions of DNA Damage to Alzheimer's Disease. Int. J. Mol. Sci. 2020, 21. [CrossRef] [PubMed]

34. Lin, X.; Gu, Y.; Tang, D. BMI1, ATM and DDR. Oncoscience 2015, 2, 665-666. [CrossRef] [PubMed]

35. Myung, N.H.; Zhu, X.; Kruman, I.I.; Castellani, R.; Petersen, R.B.; Siedlak, S.L.; Perry, G.; Smith, M.A.; Lee, H.G. Evidence of DNA damage in Alzheimer disease: Phosphorylation of histone H2AX in astrocytes. Age (Dordr) 2008, 30, 209-215. [CrossRef]

36. Shanbhag, N.M.; Evans, M.D.; Mao, W.; Nana, A.L.; Seeley, W.W.; Adame, A.; Rissman, R.A.; Masliah, E.; Mucke, L. Early neuronal accumulation of DNA double strand breaks in Alzheimer's disease. Acta Neuropathol. Commun. 2019, 7, 77. [CrossRef]

37. Mody, L.; Miller, D.K.; McGloin, J.M.; Freeman, M.; Marcantonio, E.R.; Magaziner, J.; Studenski, S. Recruitment and retention of older adults in aging research. J. Am. Geriatr. Soc. 2008, 56, 2340-2348. [CrossRef]

38. Janelsins, M.C.; Roscoe, J.A.; Berg, M.J.; Thompson, B.D.; Gallagher, M.J.; Morrow, G.R.; Heckler, C.E.; Jean-Pierre, P.; Opanashuk, L.A.; Gross, R.A. IGF-1 partially restores chemotherapy-induced reductions in neural cell proliferation in adult C57BL/6 mice. Cancer Invest. 2010, 28, 544-553. [CrossRef]

39. Han, R.; Yang, Y.M.; Dietrich, J.; Luebke, A.; Mayer-Proschel, M.; Noble, M. Systemic 5-fluorouracil treatment causes a syndrome of delayed myelin destruction in the central nervous system. J. Biol. 2008, 7, 12. [CrossRef]

40. Ladurner, A.G. Rheostat control of gene expression by metabolites. Mol. Cell 2006, 24, 1-11. [CrossRef]

41. DeBerardinis, R.J.; Chandel, N.S. Fundamentals of cancer metabolism. Sci. Adv. 2016, 2, e1600200. [CrossRef] [PubMed]

42. Boroughs, L.K.; DeBerardinis, R.J. Metabolic pathways promoting cancer cell survival and growth. Nat. Cell Biol. 2015, 17, 351-359. [CrossRef] [PubMed]

43. Hanahan, D.; Weinberg, R.A. Hallmarks of cancer: The next generation. Cell 2011, 144, 646-674. [CrossRef] [PubMed]

44. Nagarajan, A.; Malvi, P.; Wajapeyee, N. Oncogene-directed alterations in cancer cell metabolism. Trends Cancer 2016, 2, 365-377. [CrossRef] [PubMed]

45. Armitage, E.G.; Barbas, C. Metabolomics in cancer biomarker discovery: Current trends and future perspectives. J. Pharm. Biomed. Anal. 2014, 87,1-11. [CrossRef]

46. Johnson, C.H.; Ivanisevic, J.; Siuzdak, G. Metabolomics: Beyond biomarkers and towards mechanisms. Nat. Rev. Mol. Cell Biol. 2016, 17, 451-459. [CrossRef]

47. Gowda, G.A.; Zhang, S.; Gu, H.; Asiago, V.; Shanaiah, N.; Raftery, D. Metabolomics-based methods for early disease diagnostics. Expert Rev. Mol. Diagn 2008, 8, 617-633. [CrossRef]

48. Sitter, B.; Lundgren, S.; Bathen, T.F.; Halgunset, J.; Fjosne, H.E.; Gribbestad, I.S. Comparison of HR MAS MR spectroscopic profiles of breast cancer tissue with clinical parameters. NMR Biomed. 2006, 19, 30-40. [CrossRef]

49. Denkert, C.; Budczies, J.; Kind, T.; Weichert, W.; Tablack, P.; Sehouli, J.; Niesporek, S.; Konsgen, D.; Dietel, M.; Fiehn, $\mathrm{O}$. Mass spectrometry-based metabolic profiling reveals different metabolite patterns in invasive ovarian carcinomas and ovarian borderline tumors. Cancer Res. 2006, 66, 10795-10804. [CrossRef]

50. Swanson, M.G.; Vigneron, D.B.; Tabatabai, Z.L.; Males, R.G.; Schmitt, L.; Carroll, P.R.; James, J.K.; Hurd, R.E.; Kurhanewicz, J. Proton HR-MAS spectroscopy and quantitative pathologic analysis of MRI/3D-MRSI-targeted postsurgical prostate tissues. Magn Reson Med. 2003, 50, 944-954. [CrossRef]

51. Masui, K.; Cavenee, W.K.; Mischel, P.S. mTORC2 in the center of cancer metabolic reprogramming. Trends Endocrinol. Metab. 2014. [CrossRef] [PubMed] 
52. Masui, K.; Cavenee, W.K.; Mischel, P.S. mTORC2 dictates Warburg effect and drug resistance. Cell Cycle 2014, 13, 1053-1054. [CrossRef] [PubMed]

53. Phan, L.M.; Yeung, S.C.; Lee, M.H. Cancer metabolic reprogramming: Importance, main features, and potentials for precise targeted anti-cancer therapies. Cancer Biol. Med. 2014, 11, 1-19. [CrossRef] [PubMed]

54. Kroemer, G.; Pouyssegur, J. Tumor cell metabolism: Cancer's Achilles' heel. Cancer Cell 2008, 13, 472-482. [CrossRef] [PubMed]

55. Phillips, M.M.; Sheaff, M.T.; Szlosarek, P.W. Targeting Arginine-Dependent Cancers with Arginine-Degrading Enzymes: Opportunities and Challenges. Cancer Res. Treat. 2013, 45, 251-262. [CrossRef]

56. Maze, I.; Noh, K.M.; Soshnev, A.A.; Allis, C.D. Every amino acid matters: Essential contributions of histone variants to mammalian development and disease. Nature reviews. Genetics 2014, 15, 259-271. [CrossRef]

57. Schulten, H.J. Pleiotropic Effects of Metformin on Cancer. Int J. Mol. Sci. 2018, 19, 2850. [CrossRef]

58. Hopkins, B.D.; Goncalves, M.D.; Cantley, L.C. Obesity and Cancer Mechanisms: Cancer Metabolism. J. Clin. Oncol. 2016, 34, 4277-4283. [CrossRef]

59. Smuder, A.J. Exercise stimulates beneficial adaptations to diminish doxorubicin-induced cellular toxicity. Am. J. Physiol. Regul Integr. Comp. Physiol. 2019, 317, R662-R672. [CrossRef]

60. Wang, R.; Holsinger, R.M.D. Exercise-induced brain-derived neurotrophic factor expression: Therapeutic implications for Alzheimer's dementia. Ageing Res. Rev. 2018, 48, 109-121. [CrossRef]

61. Krcmery, V.; Cepcek, P. [Side effects and toxicity of new quinolones]. Bratisl. Lek Listy 1991, 92, 496-503. [PubMed]

62. Hillman, C.H.; Erickson, K.I.; Kramer, A.F. Be smart, exercise your heart: Exercise effects on brain and cognition. Nat. Rev. Neurosci. 2008, 9, 58-65. [CrossRef] [PubMed]

63. Kapogiannis, D.; Mattson, M.P. Disrupted energy metabolism and neuronal circuit dysfunction in cognitive impairment and Alzheimer's disease. Lancet Neurol. 2011, 10, 187-198. [CrossRef]

64. Scarmeas, N.; Stern, Y.; Mayeux, R.; Manly, J.J.; Schupf, N.; Luchsinger, J.A. Mediterranean diet and mild cognitive impairment. Arch. Neurol. 2009, 66, 216-225. [CrossRef] [PubMed]

65. Craft, S. The role of metabolic disorders in Alzheimer disease and vascular dementia: Two roads converged. Arch. Neurol. 2009, 66, 300-305. [CrossRef] [PubMed]

66. Llorens-Martin, M.; Torres-Aleman, I.; Trejo, J.L. Mechanisms mediating brain plasticity: IGF1 and adult hippocampal neurogenesis. Neuroscientist 2009, 15, 134-148. [CrossRef]

67. Nagahara, A.H.; Tuszynski, M.H. Potential therapeutic uses of BDNF in neurological and psychiatric disorders. Nat. Rev. Drug Discov. 2011, 10, 209-219. [CrossRef]

68. Suji, G.; Sivakami, S. Glucose, glycation and aging. Biogerontology 2004, 5, 365-373. [CrossRef]

69. Harvey, J. Leptin regulation of neuronal excitability and cognitive function. Curr. Opin. Pharmacol. 2007, 7, 643-647. [CrossRef]

70. Friedenreich, C.M.; Neilson, H.K.; Farris, M.S.; Courneya, K.S. Physical Activity and Cancer Outcomes: A Precision Medicine Approach. Clin. Cancer Res. 2016, 22, 4766-4775. [CrossRef]

71. Lahart, I.M.; Metsios, G.S.; Nevill, A.M.; Carmichael, A.R. Physical activity, risk of death and recurrence in breast cancer survivors: A systematic review and meta-analysis of epidemiological studies. Acta Oncol. 2015, 54, 635-654. [CrossRef] [PubMed]

72. Kimura, M.; Mizuta, C.; Yamada, Y.; Okayama, Y.; Nakamura, E. Constructing an index of physical fitness age for Japanese elderly based on 7-year longitudinal data: Sex differences in estimated physical fitness age. Age (Dordr) 2012, 34, 203-214. [CrossRef] [PubMed]

73. Schmitz, K.H.; Courneya, K.S.; Matthews, C.; Demark-Wahnefried, W.; Galvao, D.A.; Pinto, B.M.; Irwin, M.L.; Wolin, K.Y.; Segal, R.J.; Lucia, A.; et al. American College of Sports Medicine roundtable on exercise guidelines for cancer survivors. Med. Sci Sports Exerc. 2010, 42, 1409-1426. [CrossRef] [PubMed]

74. Erickson, K.I.; Kramer, A.F. Aerobic exercise effects on cognitive and neural plasticity in older adults. Br. J. Sports Med. 2009, 43, 22-24. [CrossRef] [PubMed]

75. Dao, E.; Hsiung, G.R.; Liu-Ambrose, T. The role of exercise in mitigating subcortical ischemic vascular cognitive impairment. J. Neurochem. 2018, 144, 582-594. [CrossRef] [PubMed]

76. Groot, C.; Hooghiemstra, A.M.; Raijmakers, P.G.; van Berckel, B.N.; Scheltens, P.; Scherder, E.J.; van der Flier, W.M.; Ossenkoppele, R. The effect of physical activity on cognitive function in patients with dementia: A meta-analysis of randomized control trials. Ageing Res. Rev. 2016, 25, 13-23. [CrossRef] [PubMed] 
77. Physical Activity Guidelines Advisory Committee Submits Scientific Report. Available online: https://health. gov/news/blog-bayw/2018/03/2018-physical-activity-guidelines-advisory-committee-submits-scientific-report/ (accessed on 18 September 2020).

78. Ashcraft, K.A.; Peace, R.M.; Betof, A.S.; Dewhirst, M.W.; Jones, L.W. Efficacy and Mechanisms of Aerobic Exercise on Cancer Initiation, Progression, and Metastasis: A Critical Systematic Review of In Vivo Preclinical Data. Cancer Res. 2016, 76, 4032-4050. [CrossRef]

79. Pedersen, L.; Idorn, M.; Olofsson, G.H.; Lauenborg, B.; Nookaew, I.; Hansen, R.H.; Johannesen, H.H.; Becker, J.C.; Pedersen, K.S.; Dethlefsen, C.; et al. Voluntary Running Suppresses Tumor Growth through Epinephrine- and IL-6-Dependent NK Cell Mobilization and Redistribution. Cell Metab. 2016, 23, 554-562. [CrossRef]

80. Heyn, P.; Abreu, B.C.; Ottenbacher, K.J. The effects of exercise training on elderly persons with cognitive impairment and dementia: A meta-analysis. Arch. Phys. Med. Rehabil 2004, 85, 1694-1704. [CrossRef]

81. Hojman, P.; Gehl, J.; Christensen, J.F.; Pedersen, B.K. Molecular Mechanisms Linking Exercise to Cancer Prevention and Treatment. Cell Metab. 2018, 27, 10-21. [CrossRef]

82. Moore, S.C.; Lee, I.M.; Weiderpass, E.; Campbell, P.T.; Sampson, J.N.; Kitahara, C.M.; Keadle, S.K.; Arem, H.; Berrington de Gonzalez, A.; Hartge, P.; et al. Association of Leisure-Time Physical Activity With Risk of 26 Types of Cancer in 1.44 Million Adults. JAMA Intern. Med. 2016, 176, 816-825. [CrossRef] [PubMed]

83. Sasso, J.P.; Eves, N.D.; Christensen, J.F.; Koelwyn, G.J.; Scott, J.; Jones, L.W. A framework for prescription in exercise-oncology research. J. Cachexia Sarcopenia Muscle 2015, 6, 115-124. [CrossRef] [PubMed]

84. Jones, L.W.; Alfano, C.M. Exercise-oncology research: Past, present, and future. Acta Oncol. 2013, 52, $195-215$. [CrossRef] [PubMed]

85. Mishra, S.I.; Scherer, R.W.; Geigle, P.M.; Berlanstein, D.R.; Topaloglu, O.; Gotay, C.C.; Snyder, C. Exercise interventions on health-related quality of life for cancer survivors. Cochrane Database Syst. Rev. 2012. [CrossRef] [PubMed]

86. Schneider, G.; Schmidt-Supprian, M.; Rad, R.; Saur, D. Tissue-specific tumorigenesis: Context matters. Nat. Rev. Cancer 2017, 17, 239-253. [CrossRef] [PubMed]

87. Vulczak, A.; Souza, A.O.; Ferrari, G.D.; Azzolini, A.; Pereira-da-Silva, G.; Alberici, L.C. Moderate Exercise Modulates Tumor Metabolism of Triple-Negative Breast Cancer. Cells 2020, 9, 628. [CrossRef] [PubMed]

88. Platten, M.; von Knebel Doeberitz, N.; Oezen, I.; Wick, W.; Ochs, K. Cancer Immunotherapy by Targeting IDO1/TDO and Their Downstream Effectors. Front. Immunol. 2014, 5, 673. [CrossRef] [PubMed]

89. Zimmer, P.; Schmidt, M.E.; Prentzell, M.T.; Berdel, B.; Wiskemann, J.; Kellner, K.H.; Debus, J.; Ulrich, C.; Opitz, C.A.; Steindorf, K. Resistance Exercise Reduces Kynurenine Pathway Metabolites in Breast Cancer Patients Undergoing Radiotherapy. Front. Oncol. 2019, 9, 962. [CrossRef]

90. Schiaffino, S.; Dyar, K.A.; Ciciliot, S.; Blaauw, B.; Sandri, M. Mechanisms regulating skeletal muscle growth and atrophy. FEBS J. 2013, 280, 4294-4314. [CrossRef]

91. Thompson, H.J.; Jiang, W.; Zhu, Z. Candidate mechanisms accounting for effects of physical activity on breast carcinogenesis. IUBMB Life 2009, 61, 895-901. [CrossRef]

(C) 2020 by the authors. Licensee MDPI, Basel, Switzerland. This article is an open access article distributed under the terms and conditions of the Creative Commons Attribution (CC BY) license (http://creativecommons.org/licenses/by/4.0/). 